Article

\title{
Ultra-Small Pd(0) Nanoparticles into a Designed Semisynthetic Lipase: An Efficient and Recyclable Heterogeneous Biohybrid Catalyst for the Heck Reaction under Mild Conditions
}

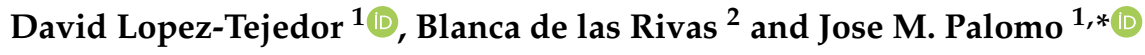 \\ 1 Department of Biocatalysis, Institute of Catalysis (CSIC), Marie Curie 2, Cantoblanco Campus UAM, \\ 28049 Madrid, Spain; david.lopez@csic.es \\ 2 Institute of Food Science, Technology and Nutrition (ICTAN-CSIC), José Antonio Novais 10, \\ 28040 Madrid, Spain; blanca.r@csic.es \\ * Correspondence: josempalomo@icp.csic.es; Tel.: +34-91-585-4768
}

Received: 27 July 2018; Accepted: 13 September 2018; Published: 14 September 2018

\begin{abstract}
A novel heterogeneous enzyme-palladium (Pd) (0) nanoparticles (PdNPs) bionanohybrid has been synthesized by an efficient, green, and straightforward methodology. A designed Geobacillus thermocatenulatus lipase (GTL) variant genetically and then chemically modified by the introduction of a tailor-made cysteine-containing complementary peptide- was used as the stabilizing and reducing agent for the in situ formation of ultra-small PdNPs nanoparticles embedded on the protein structure. This bionanohybrid was an excellent catalyst in the synthesis of trans-ethyl cinnamate by Heck reaction at $65{ }^{\circ} \mathrm{C}$. It showed the best catalytic performance in dimethylformamide (DMF) containing $10-25 \%$ of water as a solvent but was also able to catalyze the reaction in pure DMF or with a higher amount of water as co-solvent. The recyclability and stability were excellent, maintaining more than $90 \%$ of catalytic activity after five cycles of use.
\end{abstract}

Keywords: heterogeneous catalyst; palladium nanoparticles; semisynthetic enzyme; lipase; Heck reaction

\section{Introduction}

The Heck reaction is one of the most studied coupling reactions for its usefulness, allowing the catalytic construction of $\mathrm{C}-\mathrm{C}$ bonds under relatively mild conditions $[1,2]$. It has been widely used for the synthesis of a huge spectrum of molecules, natural products, polymers, and pharmaceuticals on both the laboratory and industrial scale. Some of the most notable products obtained using this method are Naproxen, Montelukast (Singulair), octyl-4-methoxycinnamate (present on UVB sunscreen), Electriptan or Leuconolam (Figure 1) [3,4]. 


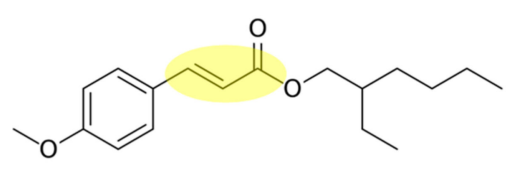

octyl-4-methoxycinnamate

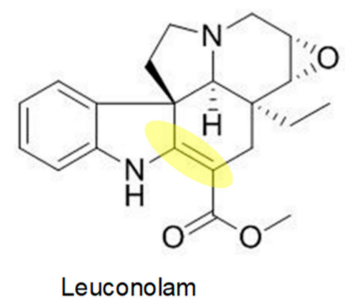

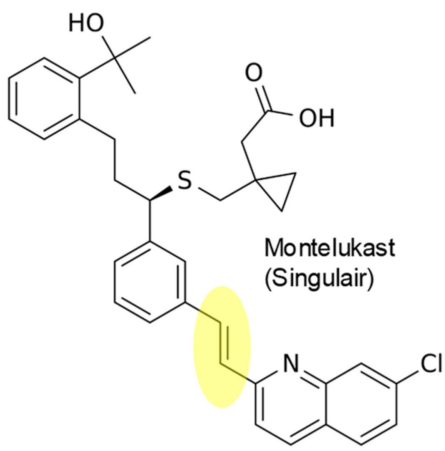

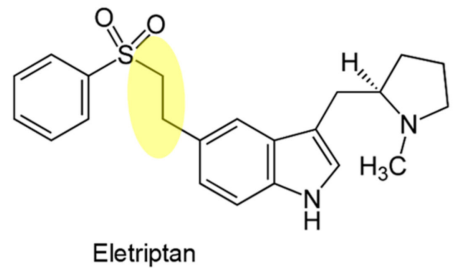

Figure 1. Pharmaceuticals synthesized by using Heck cross-coupling reaction.

Several metals and a huge range of ligands have been studied as catalysts for the reaction, with palladium $(\mathrm{Pd})$ the preferred metal due to its tolerance to a wide variety of functional groups and ability to form $\mathrm{C}-\mathrm{C}$ bonds between functionalized substrates, proceeding with stereo and regioselectivity and, usually, with good to excellent yields [2]. Investigation towards palladium-catalyzed Heck reaction has been focused on greener approaches to the reaction, performing it in aqueous media, and being able to recover and reuse the catalyst, which is quite important for industrial purposes [5-8].

In particular, the application of Pd nanoparticles as catalysts presents important advantages compared to other Pd molecules due to the high surface-to-volume ratio and very active surface atoms $[9,10]$.

As described for other types of Pd complexes, optimization in the synthetic conditions to avoid hard or extreme conditions in the synthesis of Pd nanoparticles is greatly desirable. The application of biomolecules to induce the synthesis of these nanoparticles has been recently described [11]. The application of carbohydrates, peptides, polymers or microorganisms has been successfully applied [6-8,11-14]. However, in some cases, the generation of large size nanoparticles, not well dispersed or even a mixture in the nanoparticle morphology by using these biomolecules, have made the application of enzymes as a biological entity the best alternative to the ones mentioned before [11,15].

However, for possible industrial implementation of this type of catalyst, enzyme production is a key point. Although this can be obtained from commercial suppliers, it is important to have a good and consistent production source to obtain enough enzyme to be translated into high volumes of the final nanobiomaterials. In addition, enzymes with good stability might be interesting for application on reactions in harsh conditions, high temperatures or in the presence of organic solvents.

In this work, we have synthesized a novel palladium (Pd) (0) nanoparticle (PdNPs)-enzyme nanobiohybrid using a tailor-made designed enzyme to induce the formation of ultra-small Pd NPs into the protein network.

Thermoalkalophilic lipase from Geobacillus thermocatenulatus (GTL) was genetically modified by introducing an unique cysteine (Cys) in a particular position and was overexpressed in Eschericia coli. The recombinant enzyme was then modified site-specifically by using a cysteine-containing peptide via disulfide exchange chemistry. This novel bionanohybrid was characterized by transmission electron microscopy (TEM) and X-ray diffraction (XRD) to confirm the existence of zero valent $\mathrm{Pd}$ and the final size and morphology of the nanoparticles. 
The potential synthetic application of this Pd-enzyme bionanohybrid as nanocatalyst was evaluated in Heck Cross-Coupling reaction under different conditions. Stability and reusability of the heterogeneous catalyst were also evaluated.

\section{Results and Discussion}

\subsection{Synthesis and Characterization of the Bionanohybrid}

First, a tailor-made enzyme was created following the protocol previously described [16,17]. Lipase from Geobacillus thermocatenulatus (GTL) was genetically modified by site-directed mutagenesis, changing Ala193 to Cys (Figure 2), without alteration in the properties of the enzyme. This GTLo-A193C variant was overexpressed in Escherichia coli and purified, which permitted to obtain a high amount of protein.

Then, this new enzyme solution was combined with palladium acetate to create a new kind of bionanohybrid; nanocatalysts formed by in situ synthesized palladium nanoparticles in the protein network [18]. The formation of the bionanohybrid can be easily recognized by the increase in turbidity of the solution, which is precipitated after centrifugation.
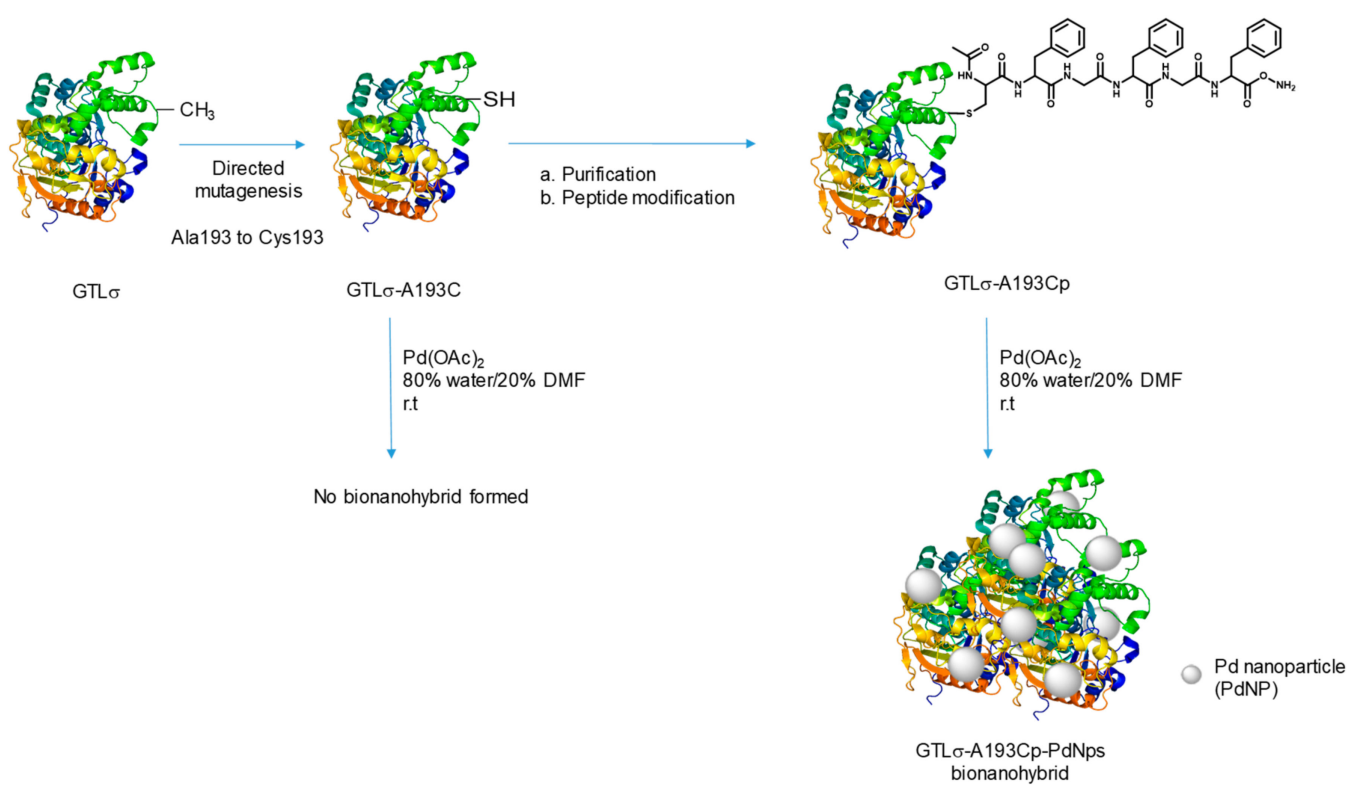

Figure 2. Preparation of the Geobacillus thermocatenulatus (GTL) $\sigma$-A193Cp-palladium (0) nanoparticles (PdNPs) bionanohybrid.

In this case, no aggregate was obtained when the GTL $\sigma$-A193C and palladium salt mixture was incubated for $24 \mathrm{~h}$ at room temperature, with the solution remaining completely transparent. This result indicated that no bionanohybrid could be formed when using this genetically modified protein.

Therefore, this GTLo-A193C was site-specific chemically modified at the cysteine by a Cys-containing peptide (Ac-Cys $\left.(\mathrm{PheGly})_{2} \mathrm{PheCONH}_{2}\right)$ (Figure 2$)$. First, the cysteine on the protein (C193) was protected with 2-dipyridiyldisulfide before the reaction. Then the peptide was conjugated to the Cys193 by a disulfide bond exchange. This modification generated a new semisynthetic GTL lipase (GTLo-A193Cp) with improved properties and specifically increased the hydrophobicity of the final protein structure [16].

Thus, the protocol for the bionanohybrid synthesis was applied using this new enzyme GTLo-A193Cp. In this case, the solution turned cloudy in the first hour of incubation and finally aggregate was obtained after $24 \mathrm{~h}$ (Figure 2). The solid was recovered by centrifugation, washed and lyophilized. X-ray diffraction (XRD) analysis showed that zero-valent Pd was the only species present in the bionanohybrid (Figure 3). 


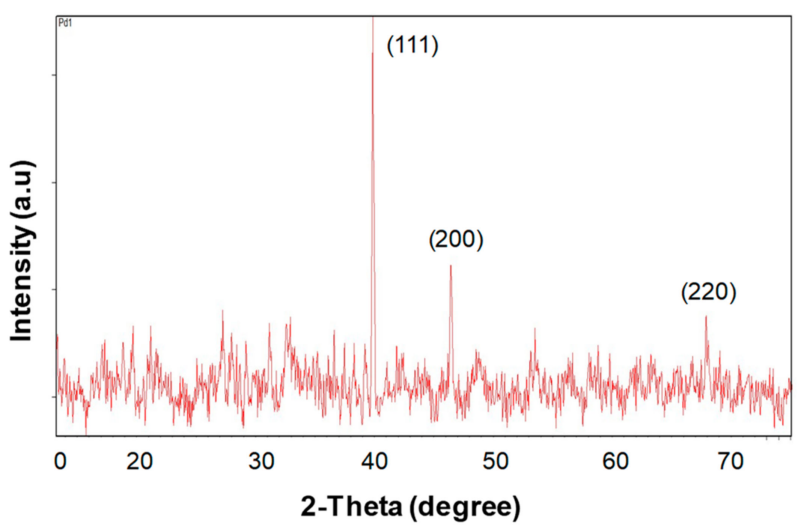

Figure 3. X-ray diffraction (XRD) pattern of GTL $\sigma$-A193Cp-PdNPs bionanohybrid.

The content of palladium in the solid was $40 \mathrm{wt} . \%$ measured by inductively coupled plasma atomic emission spectrometry (ICP-OES). More than $99 \%$ of the enzyme offered was remaining in the final bionanohybrid confirmed by Bradford assay [19]. TEM analysis showed that ultra-small spherical

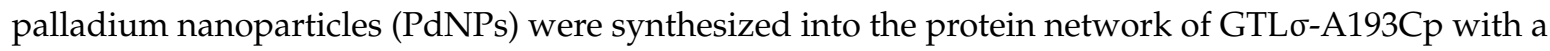
size distribution of 2 to $4 \mathrm{~nm}$, but mainly with a size around $3 \mathrm{~nm}$ (Figure 4 ).

a)

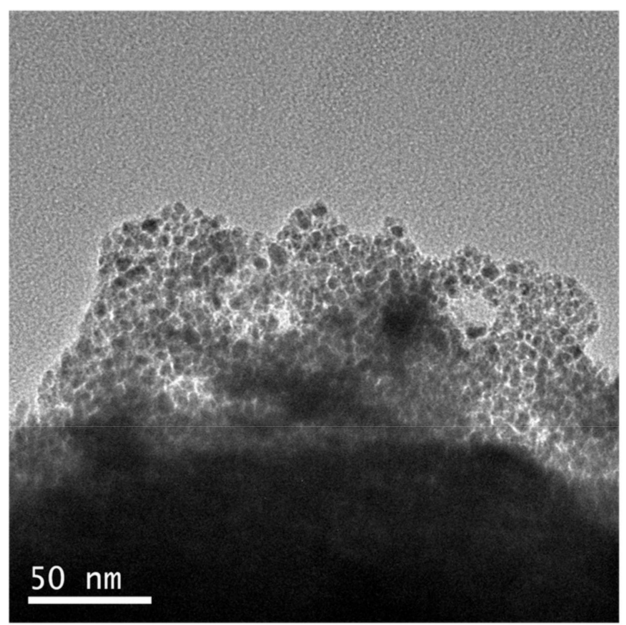

c)

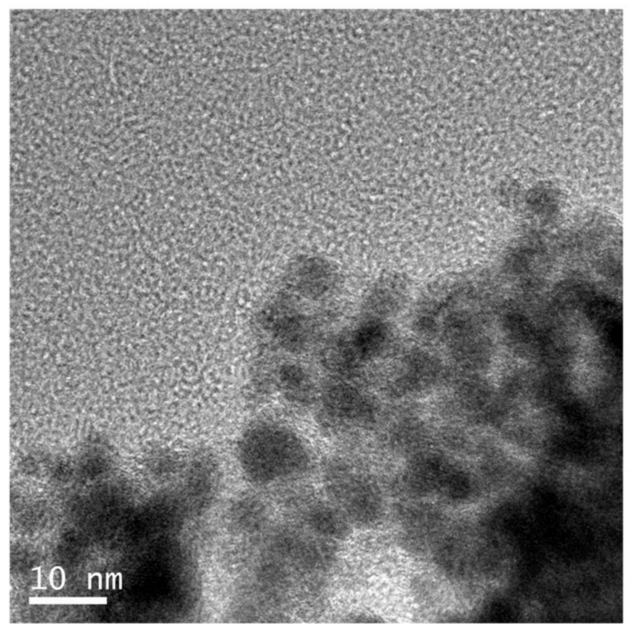

b)

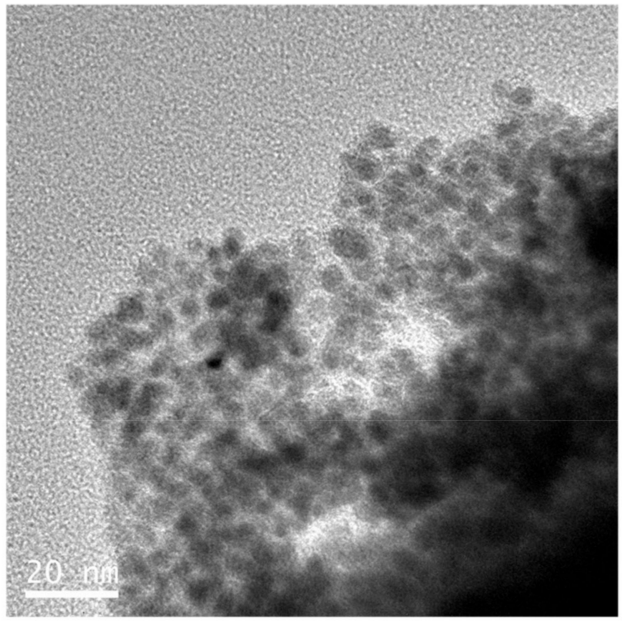

d)

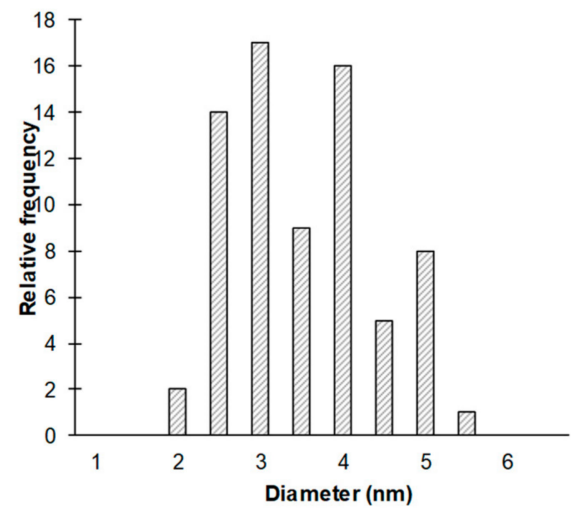

Figure 4. Characterization of GTL $\sigma-A 193 C \mathrm{p}-\mathrm{PdNPs}$ bionanohybrid. (a-c) transmission electron microscopy (TEM) and high resolution TEM (HRTEM) micrographs. (d) Pd NPs size distribution. 
The proposed mechanism for the formation of this enzyme-metal nanobiohybrid consists in two different steps, (i) The ionic binding of the $\mathrm{Pd}^{2+}$ ions with different aminoacid residues of the protein, and (ii) the nucleation, reduction of $\mathrm{Pd}^{2+}$ to $\mathrm{Pd}(0)$ with the final growth of the nanoparticle. One of the important points in this mechanism is the role of aminoacids and small peptide sequences into the protein involved during the nanobiohybrid formation. The phenomenon that peptides sequences can be reduced metal ions has been well studied using tailor-made synthetic small peptides. Therefore, the protein in question must contain particular peptides sequences, the so-called ideal peptides, which has to contain amino acids with moderate binding affinity for both metal ions and formed metal particles (i.e., amino acids presenting hydrophobic or charged side chains (with the charge sign opposite to that showed by the metal ions)) together with neighboring amino acids showing a strong reducing ability (i.e., especially amino acids presenting hydrophobic side chains, or particularly alcohol residues such as serines, threonines or tyrosines) [18].

Thus, adding the metal salt to the enzyme solutions, due to the binding ability of the identified sequences, rapid adsorption of soluble Pd ions on the enzyme surface was observed. Furthermore, the adsorbed metal ions act as a cross-linker between the enzyme's molecules, reducing their solubility and finally inducing the initial fast precipitation. When the metal ions are adsorbed, the amino acids in protein surrounding them caused the nucleation.

The structural analysis of the chemically modified variant demonstrated that the site-specific location of the hydrophobic peptide (Figure 5) was critical, considering the necessity of hydrophilic groups together to hydrophobic ones for the reducing step. Serine, threonine, tyrosine or even methionine were surrounded by the peptide (Figure 5). These groups were able to reduce the adsorbed $\mathrm{Pd}^{2+}$ to $\mathrm{Pd}(0)$, which is mandatory for the nucleation process [18].

In contrast, the native variant without the peptide also presented a hydrophobic area on the lid side (Figure S1, see Supplementary Materials), and although it could be possible from the initial adsorption of $\mathrm{Pd}^{2+}$, no adequate hydrophilic groups were surrounding that position which could demonstrate why the native variant was unable to form the bionanohybrid.

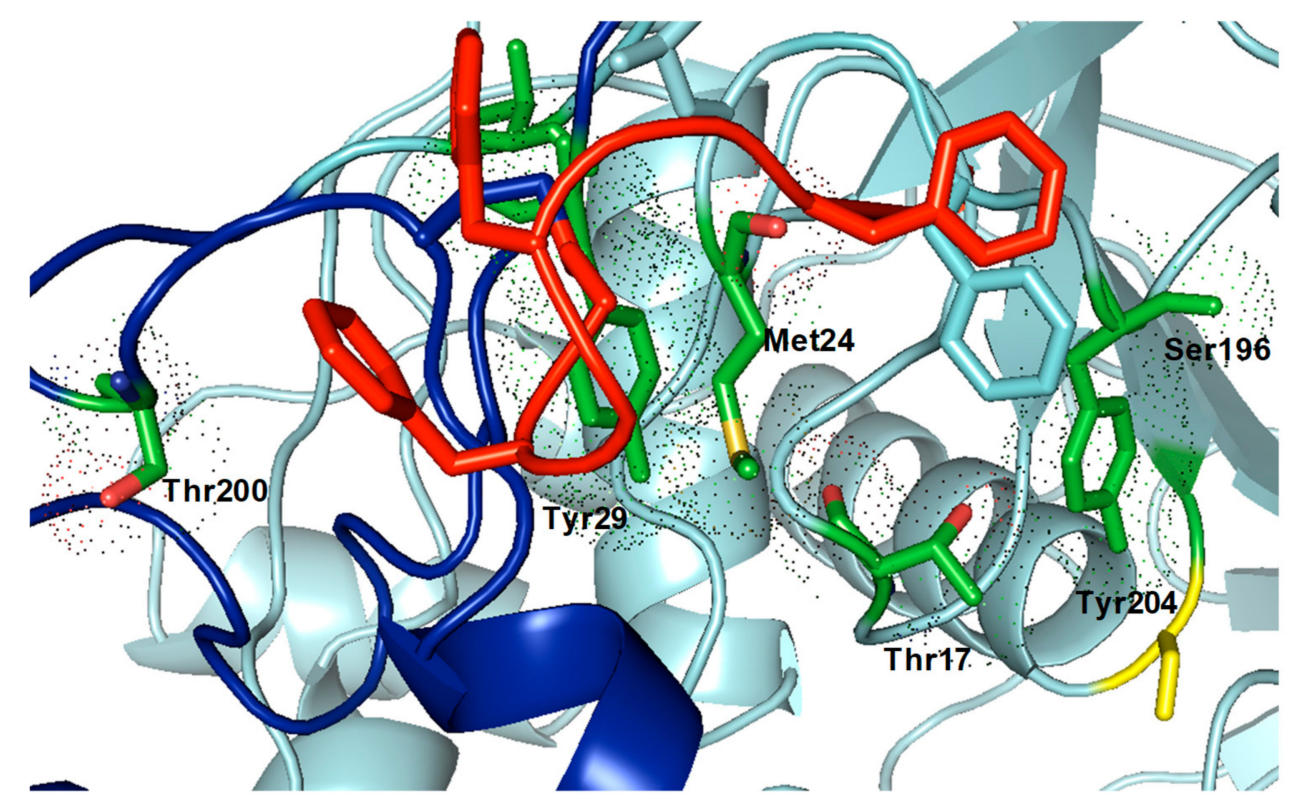

Figure 5. Crystal structure of the active form of the artificial enzyme GTL $\sigma$-A193Cp. Cartoon of the peptide sequence and the selected alcoholic protein residues. A193C-catalytic Ser114 is marked in yellow, lid in blue, peptide in red and the different Ser, Thr, Tyr or Met residues in green. All pictures were created by using Pymol. 


\subsection{Heck Reaction}

Thus, this new GTL $\sigma$-A193Cp-PdNPs bionanohybrid was tested as a heterogeneous catalyst in Heck reaction using iodobenzene (1) and ethyl acrylate (2) as substrates (Scheme 1). The reaction was performed at moderate conditions, in an aqueous solution, containing $75 \%(v / v)$ dimethylformamide (DMF) and $65^{\circ} \mathrm{C}$.

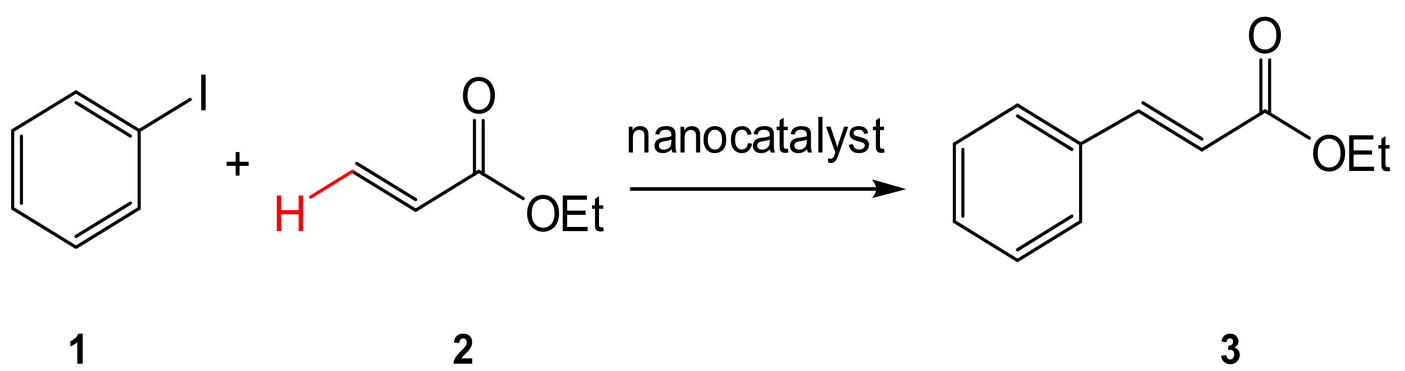

Scheme 1. C-C Heck reaction catalyzed by bionanohybrid.

The $\mathrm{C}-\mathrm{C}$ reaction was evaluated using different bases in the reaction (Table 1). The application of dimethylaminopyridine (DMAP) as the base resulted in no conversion (Table 1, entry 1). The nanocatalyst exhibited around $20 \%$ conversion after $24 \mathrm{~h}$ when the combination of DMAP and triethylamine was used (Table 1, entry 2). The best result was obtained using triethylamine, where $78 \%$ of ethyl cinnamate (3) was obtained with a TOF value of $2.96 \mathrm{~h}^{-1}$, more than three times compared with the use of DMAP and with a complete reaction ( $>99 \%)$ at $48 \mathrm{~h}$ (Table 1, entry 3 ). In addition, diisopropylethylamine (DIPEA) was evaluated, although the achieved conversion was slightly lower after $24 \mathrm{~h}$ compared to the one with triethylamine (Table 1) with a TOF value of $2.32 \mathrm{~h}^{-1}$. In all cases where a reaction was obtained, a high selectivity was achieved, producing the trans-isomer exclusively.

Table 1. Heck coupling of iodobenzene with ethyl acrylate catalyzed by GTL $\sigma-A 193 C p-P d N P s$ bionanohybrid ${ }^{[a]}$.

\begin{tabular}{cccccc}
\hline Entry & Base & $\begin{array}{c}\text { Conversion of } 3 \\
{[\%]}\end{array}$ & TON & $\begin{array}{c}\text { TOF } \\
\left(\mathbf{h}^{-\mathbf{1}} \mathbf{)}\right.\end{array}$ & $\begin{array}{c}\text { Selectivity } \\
\text { trans/cis (\%) }\end{array}$ \\
\hline 1 & $\mathrm{DMAP}$ & 0 & - & - & - \\
2 & $\mathrm{DMAP/NEt}_{3}$ & 20 & 18.27 & 0.76 & $>99$ \\
3 & $\mathrm{NEt}_{3}$ & $78(>99)[\mathrm{b}]$ & $71.2(91.33)$ & $2.96(1.90)$ & $>99$ \\
4 & $\mathrm{DIPEA}_{5}$ & 61 & 55.7 & 2.32 & $>99$ \\
6 & $\mathrm{NEt}_{3}$ & $44^{[\mathrm{c}]}$ & 40.2 & 1.67 & $>99$ \\
7 & $\mathrm{NEt}_{3}$ & $7 \mathrm{~d}]$ & 6.4 & 0.27 & $>99$ \\
\hline
\end{tabular}

[a] Conditions: 1 ( $0.274 \mathrm{mmol}), 2(0.55 \mathrm{mmol}), 1 \mathrm{~mL} \mathrm{DMF} / \mathrm{H}_{2} \mathrm{O}(75 / 25), 1.5$ equiv base, $1 \mathrm{mg}$ of nanocatalyst, $24 \mathrm{~h}$, $65^{\circ} \mathrm{C}^{[\mathrm{b}]}$ after 48 h. ${ }^{[\mathrm{c}]} 5$ equiv base. ${ }^{[\mathrm{d}]} 10$ equiv base. ${ }^{\text {[e] }} 10$ equiv 2.

The increase in the amount of triethylamine in the reaction catalyzed by GTL $\sigma$-A193Cp-PdNPs bionanohybrid was studied. This addition caused a slight negative effect in the final conversion value, with 5 eq obtaining $41 \%$ of 3 , but especially after 10 eq, where only $7 \%$ of 3 was achieved after $24 \mathrm{~h}$ (Table 1, entries 5 and 6), a TOF value of $0.27 \mathrm{~h}^{-1}, 15$ times lower compared when 1.5 equivalent was used. The increase of 2 also showed a negative effect on the final conversion value (Table 1, entry 7).

For a possible industrial application, the recyclability of the heterogeneous nanocatalyst was studied. The GTLo-A193Cp-PdNPs bionanohybrid was used in at least five cycles of Heck reaction at $25 \%$ water in DMF at $65{ }^{\circ} \mathrm{C}$. The nanocatalysts kept $90-95 \%$ of the initial activity while also maintaining a complete trans selectivity (Figure 6). 


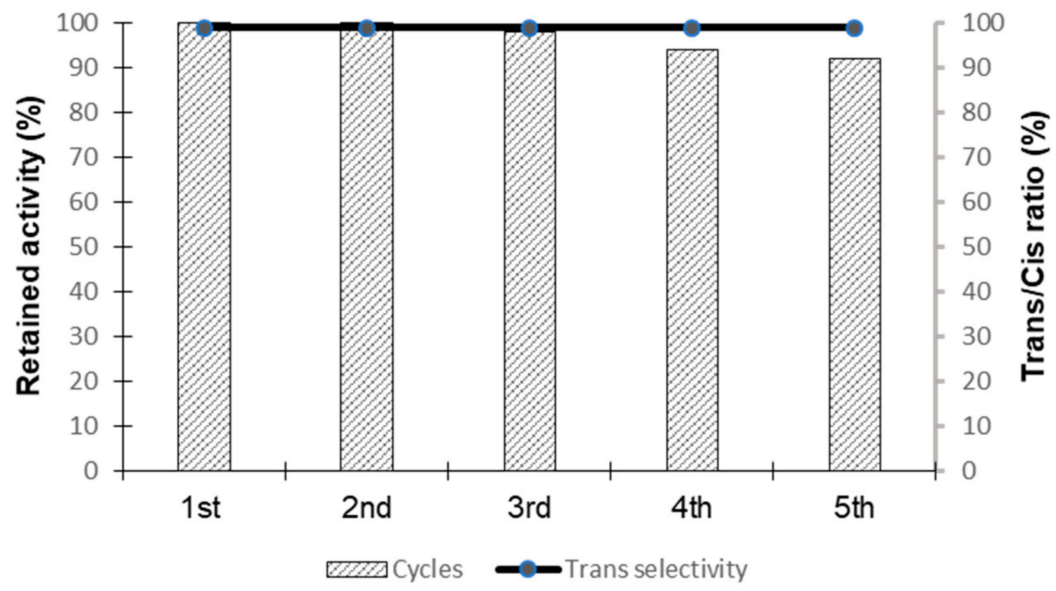

Figure 6. Recyclability of GTL $\sigma-A 193 \mathrm{Cp}-\mathrm{PdNPs}$ bionanohybrid in the Heck reaction. Conditions: $1(0.274 \mathrm{mmol}), 2(0.55 \mathrm{mmol}), 1 \mathrm{~mL} \mathrm{DMF} / \mathrm{H}_{2} \mathrm{O}(75 / 25), 1.5$ equiv $\mathrm{NEt}_{3}, 1 \mathrm{mg}$ of nanocatalyst, $65^{\circ} \mathrm{C}$.

To evaluate the capacity of this nanocatalyst, the Heck reaction was performed changing the volume of water in the reaction medium. The reduction in the volume of water in the medium was first attempted. Surprisingly, the bionanohybrid catalyzed the reaction faster when only $10 \%$ water was used, obtaining $86 \%$ conversion of 3 after $24 \mathrm{~h}$, with a TOF value of $3.27 \mathrm{~h}^{-1}$ (Table 2, entry 2).

Table 2. Heck coupling of iodobenzene with ethyl acrylate catalyzed by GTL $\sigma-A 193 C p-P d N P s$ bionanohybrid as catalyst at different aqueous content. [a]

\begin{tabular}{cccccccc}
\hline Entry & $\begin{array}{c}\text { Co-Solvent } \\
{\left[\% \text { v/v, } \mathbf{H}_{\mathbf{2}} \mathbf{O}\right]}\end{array}$ & $\begin{array}{c}\mathbf{T} \\
{\left[{ }^{\mathbf{O}} \mathbf{C}\right]}\end{array}$ & $\begin{array}{c}\text { Conversion } \\
\text { of } \mathbf{3}[\mathbf{\%}]\end{array}$ & $\mathbf{T O N}$ & $\begin{array}{c}\text { TOF } \\
\left(\mathbf{h}^{-\mathbf{1}}\right)\end{array}$ & $\begin{array}{c}\text { Selectivity } \\
\text { trans/cis } \mathbf{( \% )}\end{array}$ & Reference \\
\hline 1 & 0 & 65 & 56 & 51.15 & 2.13 & $>99$ & This work \\
2 & 10 & 65 & 86 & 78.54 & 3.27 & $>99$ & This work \\
3 & 25 & 65 & 78 & 71.23 & 2.96 & $>99$ & This work \\
4 & 40 & 65 & 50 & 45.65 & 1.90 & $>99$ & This work \\
5 & 0 & 70 & 0 & - & - & - & {$[18]$} \\
7 & 50 & 70 & 20 & 18.27 & 0.76 & $>99$ & {$[18]$} \\
\hline
\end{tabular}

A very interesting result was also obtained when the reaction was performed in pure DMF as the solvent. The GTL $\sigma$-A193Cp-PdNPs bionanohybrid catalyzed the Heck reaction with 56\% conversion after $24 \mathrm{~h}$, TOF value of $2.13 \mathrm{~h}^{-1}$, with exclusively trans selectivity (Table 2, entry 1 ). This differed from the results previously obtained using bionanohybrid synthesized using other lipase where no conversion was achieved even at higher temperatures (Table 2, entry 5). This phenomenon could demonstrate that the application of a highly stable protein variant of GTL allows broader applicability of the final Pd NPs biohybrid in synthetic chemistry.

This argument was also corroborated when higher volumes of water were added to DMF as the solvent. This bionanohybrid also catalyzed the Heck reaction in the presence of $40 \%$ of water in DMF at $65^{\circ} \mathrm{C}$, with a TOF value of $1.90 \mathrm{~h}^{-1}$ (Table 2, entry 4), better than the previous comparison (Table 2, entry 7). In addition, in all cases, the trans-selectivity was conserved.

To demonstrate the broad scope of applicability of this new bionanohybrid, Suzuki cross-coupling reaction between bromobenzene and phenylboronic acid in aqueous media at mild conditions reaction in pure water was attempted (Table S1, see Supplementary Materials). The GTLo-A193Cp-PdNPs showed good performance producing $70 \%$ conversion of biphenyl in $24 \mathrm{~h}$ at $50{ }^{\circ} \mathrm{C}$ in aqueous media, with a TOF value of 0.43 (Table S1). Furthermore, Sonogashira reaction between propargyl alcohol and iodoanisole was performed (Table S2). 


\section{Materials and Methods}

\subsection{General}

Butyl-Sepharose ${ }^{\circledR} 4$ Fast Flow from GE Healthcare (Uppsala, Sweden), 2-dipyridyldisulfide (2-PDS), dithiothreitol (DTT), sodium borohydride, dimethylsulfoxide (DMSO), dimethylformamide (DMF), dimethylaminopyridine (DMAP), diisopropylethylamine (DIPEA), p-nitrophenylpropionate (pNPP), $\mathrm{Pd}(\mathrm{OAc})_{2}$, ethyl-acrylate, iodobenzene, cis and trans ethyl cinnamate, and triethylamine were from Sigma (St. Louis, MO, USA). Sucrose monolaurate was from Mitsubishi-Kagaku (Tokyo, Japan). AcN-Cys(SH)-Phe-Gly-Phe-Gly-Phe-CONH 2 was purchased from Isogen (De Meern, Netherlands). Inductively coupled plasma atomic emission spectrometry (ICP-OES) of the acidic digestion of the solid powder of bionanohybrid was performed on a Perkin Elmer OPTIMA 2100 DV equipment. The transmission electron microscopy (TEM), high resolution TEM microscopy (HRTEM) were performed on a JEOL 2100F microscope equipped with an EDX detector INCA x-sight (Oxford Instruments, Tokyo, Japan). The X-ray diffraction (XRD) pattern was obtained using a Texture Analysis Diffractometer D8 Advance (Bruker) with $\mathrm{Cu} \mathrm{K} \alpha$ radiation.

\subsection{Site-Directed Mutagenesis, Cloning, and Expression of Geobacillus Thermocatenulatus Lipase (GTL)}

All site-directed mutagenesis experiments were carried out by polymerase chain reaction (PCR) using mutagenic primers. To introduce the amino acid change, the corresponding pair of primers was used as a homologous primer pair in a PCR reaction using a specific plasmid as template and Prime Start HS Takara DNA polymerase. The product of the PCR was digested with endonuclease DpnI that exclusively restricts methylated DNA [20]. E. coli DH10B cells were transformed directly with the digested product. The plasmid with mutated GTL was identified by sequencing and then transformed into E. coli BL21 (DE3) cells to express the corresponding proteins. First, C65S was created, and the resulting plasmid was used as a template to create the double mutant C65S/C296S-GTL (GTL $\sigma$ ). This plasmid (pT1BGTLmutCys) was used as a template to construct the additional mutation (A193C), creating the mutant GTLo-A193C using different mutagenic primers: A193C (Ala/cys 193-5,5'-GAAAGCGtgcGCTGTCGCCAG; Ala/cys 193-3 5'-CTGGCGACAGCg caCGCTTTC). The gene corresponding to the mature lipase from G. thermocatenulatus (GTL) was cloned into a pT1 expression vector as previously described in Reference [20]. Cells carrying the recombinant plasmid pT1GTL were grown at $30{ }^{\circ} \mathrm{C}$ and over expression was induced by raising the temperature to $42{ }^{\circ} \mathrm{C}$ for $20 \mathrm{~h}$.

\subsection{Purification of GTL $\sigma-A 193 C$}

The crude extract from E. coli containing the GTL variant was diluted with $10 \mathrm{mM}$ sodium phosphate at $\mathrm{pH} 7.0$ to a concentration of $0.5 \mathrm{mg} / \mathrm{mL}$. Then, butyl-Sepharose was added in a $1 / 20(v / v)$ proportion and gently stirred overnight at $25{ }^{\circ} \mathrm{C}$. Periodically, the activity of suspensions and supernatants were measured by the pNPP assay described above. After that, the adsorbed lipase preparation was abundantly washed with distilled water. Purification overall yield was $80 \%$ confirmed by sodium dodecyl sulfate polyacrylamide gel electrophoresis (SDS-PAGE) analysis and a decrease in the supernatant activity.

\subsection{Irreversible Site-Specific Chemical Modification of GTL $\sigma$-A193C by Thiol-Containing Peptides}

GTL $\sigma-A 193 C$ adsorbed on butyl-Sepharose (0.2 g) was incubated in $2 \mathrm{~mL}$ of DTT solution (50 mM in $25 \mathrm{mM}$ sodium phosphate buffer) at $\mathrm{pH} 8$ for $30 \mathrm{~min}$, to avoid oxidation and permit the posterior disulfide exchange. After, the reduced biocatalyst was washed with distilled water until the DTT smell disappears. Then $0.2 \mathrm{~g}$ of the reduced biocatalyst was added to $3 \mathrm{~mL}$ of 2-PDS solution (1.5 $\mathrm{mM}$ substrate in a mixture of DMSO $(5 \% v / v)$ in $25 \mathrm{mM}$ phosphate buffer) at $\mathrm{pH} 8.0$ for $1 \mathrm{~h}$, and then the suspension was abundantly washed with distilled water. The full cysteine PDS activation was confirmed by spectrophotometric assay. Then, $1 \mathrm{~mL}$ of AcN-Cys(SH)-Phe-Gly-Phe-Gly-Phe-CONH 2 (p) solution $(0.2 \mathrm{mg} / \mathrm{mL})$ was added to the $2 \mathrm{~mL}$ of PDS-GTL variant for $1 \mathrm{~h}$. The peptide $(\mathrm{p})$ was 
previously treated with a solution of sodium borohydride $(1 \mathrm{mg} / \mathrm{mL})$ in $250 \mathrm{mM}$ phosphate at $\mathrm{pH}$ 10.0 for $30 \mathrm{~min}$ (to conserve the thiol group in a reductive form), and then $\mathrm{pH}$ was adjusted to 8.0 with diluted $\mathrm{HCl}$ solution to destroy the remaining sodium borohydride.

After that, the chemically modified GTL variant was incubated in $2 \mathrm{~mL}$ of $1.25 \%(v / v)$ sucrose monolaureate in $250 \mathrm{mM}$ phosphate at $\mathrm{pH} 8.0$ for $1 \mathrm{~h}$, and the full desorption of the modified GTLo-A193Cp variant was confirmed by activity assay and SDS electrophoresis. This solution had an approximate protein concentration of $0.9 \mathrm{mg} / \mathrm{mL}$.

\subsection{Enzymatic Activity of the Artificial GTL Variants on Hydrolysis of p-Nitrophenyl Propionate ( $p N P P$ )}

The activity of the GTL variants was analyzed spectrophotometrically measuring the increment in absorbance at $348 \mathrm{~nm}$ produced by the release of $p$-nitrophenol (pNP) $\left(\epsilon=5150 \mathrm{M}^{-1} \mathrm{~cm}^{-1}\right)$ in the hydrolysis of $0.4 \mathrm{mM}$ pNPP in $25 \mathrm{mM}$ sodium phosphate at $\mathrm{pH} 7$ and $25^{\circ} \mathrm{C}$. To initialize the reaction, $0.05-0.2 \mathrm{~mL}$ of lipase solution or suspension was added to $2.5 \mathrm{~mL}$ of substrate solution.

\subsection{Synthesis of GTL $\sigma$-A193Cp-PdNPs Bionanohybrid}

$\mathrm{Pd}(\mathrm{OAc})_{2}(5 \mathrm{mg})$ was dissolved in $1 \mathrm{~mL}$ of DMF and then added to $4 \mathrm{~mL}$ of GTL $\sigma$-A193Cp solution (the previously desorbed enzyme solution was diluted $1: 1$ with distilled water, obtaining $0.45 \mathrm{mg} / \mathrm{mL}$ solution) under vigorous magnetic stirring at $25^{\circ} \mathrm{C}$. The amount of solvent $(20 \% v / v)$ was needed to ensure the full dissolution of the palladium salt in aqueous media. The solution was kept on gentle magnetic stirring for $24 \mathrm{~h}$ at room temperature. The resulting final suspension was separated by centrifugation ( $8000 \mathrm{rpm} ; 4{ }^{\circ} \mathrm{C} ; 35 \mathrm{~min}$ ), and the recovered pellet was washed two times with a $20 \%$ $v / v \mathrm{DMF} /$ distilled water solution for the removal of the remainders of palladium salt, and two more times with $5 \mathrm{~mL}$ of distilled water. After the last washing, the suspension was lyophilized to obtain the solid for characterization and use in the reaction.

\subsection{General Procedure for Heck Reaction}

The reaction mixture was prepared in a screw-sealed glass vessel, containing $1 \mathrm{~mL}$ of solvent solution (either $1 \mathrm{~mL}$ of pure DMF or DMF/water), $0.274 \mathrm{mmol}(30 \mu \mathrm{L})$ of iodobenzene and $0.55 \mathrm{mmol}$ $(59 \mu \mathrm{L})$ of ethylacrylate. This solution was preheated at $65^{\circ} \mathrm{C}$ for 5 min under magnetic stirring for the complete solubilization of the substrates; then, $1 \mathrm{mg}$ of palladium catalyst was added to the mixture (containing $0.4 \mathrm{mg}$ of Pd) as well as $0.412 \mathrm{mmol}$ of a base (either triethylamine, DMAP or DIPEA) and was kept under vigorous magnetic stirring at $65^{\circ} \mathrm{C}$ for the indicated times. Samples $(80 \mu \mathrm{L})$ were taken at different times, and the reaction was followed by HPLC. Samples were first centrifuged at $8000 \mathrm{rpm}$ for $5 \mathrm{~min}$, and then $10 \mu \mathrm{L}$ was diluted 1000 times in a solution of acetonitrile:water 1:1. The reaction outgoing was monitored by HPLC analysis of the reaction samples at different times. The analysis conditions were performed with a Kromasil-C $8(150 \times 4.6 \mathrm{~mm}$ and $5 \mu \mathrm{m} \varnothing)$, at a flow of $1.0 \mathrm{~mL} / \mathrm{min}$; $\lambda: 254 \mathrm{~nm}$; and a mobile phase: $50 \%(v / v) \mathrm{ACN}$ in MilliQ water. In these conditions, the retention times were: $4.18 \mathrm{~min}$ for ethyl acrylate (2), $11.1 \mathrm{~min}$ for (E)-trans ethyl cinnamate (3) and $13.25 \mathrm{~min}$ for iodobenzene (1). The E configuration was confirmed by HPLC using the (E) and (Z)-3 standards. Retention time for the (Z)-3 was 10.35 min (see Supplementary Materials).

\subsection{Recyclability Test}

The protocol for Heck reaction mentioned previously was followed, using triethylamine as a base and $75 \%(v / v)$ DMF in water as a solvent. After each cycle (stopping the reaction around $50 \%$ conversion), the reaction solution was centrifuged, and the nanobiohybrid was washed two times with DMF and left to dry for $15 \mathrm{~min}$ in a fume hood. This recyclability test was performed for five cycles. 


\section{Conclusions}

Herein we have demonstrated the applicability of a new kind of Pd bionanohybrid in the Heck reaction.

A recombinant lipase from Geobacillus thermocatenulatus was selected, which was genetically modified by introducing a cysteine at position 193 and then this cysteine modified with a tailor-made peptide. This designed semisynthetic lipase was applied successfully to produce a heterogeneous bionanohybrid formed by ultra-small Pd nanoparticles embedded on the protein network. The applicability of a recombinant protein to produce the hybrid would permit to the accessibility of reproducible and multi-milligram scaled bionanohybrid. The use of a thermoalkalophilic enzyme in the formation of the nanobiohybrid is an advantage, which was demonstrated by this new hybrid catalyzing the Heck reaction in pure DMF at $65^{\circ} \mathrm{C}$, in comparison with other bionanohybrid using another lipase where no conversion was observed at these conditions [18]. The bionanohybrid was excellent using $10 \%$ water $(v / v)$ as co-solvent in DMF and was quite stable being recyclable without losing the activity or trans-selectivity.

Therefore, these results demonstrate that this could be an excellent candidate for application in organic synthesis, even in harsh conditions.

Supplementary Materials: The following are available online: Figure S1: Crystal structure of GTL native and modified together with the lid area marked key amino acids, Table S1: Suzuki-Miyaura cross coupling of bromobenzene (BB) with phenylboronic acid (PBA) catalyzed by bionanohybrid, Table S2: Suzuki-Miyaura cross coupling of bromobenzene (BB) with phenylboronic acid (PBA) catalyzed by bionanohybrid.

Author Contributions: D.L.-T. and B.d.l.R. performed the experiments; J.M.P. designed and supervised the study and experiments, and J.M.P. and D.L.-T. wrote the manuscript.

Funding: This work has been sponsored by the Spanish Government (Project AGL2017-84614-C2-2-R) and CSIC Project CSIC-PIE 201880E011).

Acknowledgments: The authors thank the support by the Spanish National Research Council (CSIC).

Conflicts of Interest: The authors declare no conflicts of interest.

\section{References}

1. Beletskaya, I.P.; Cheprakov, A.V. Heck reaction as a sharpening stone of palladium catalysis. Chem. Rev. 2000, 100, 3009-3066. [CrossRef] [PubMed]

2. Jagtap, S. Heck Reaction-State of the Art. Catalysts 2017, 7, 267. [CrossRef]

3. Magano, J.; Dunetz, J.R. Large-scale applications of transition metal-catalyzed couplings for the synthesis of pharmaceuticals. Chem. Rev. 2011, 111, 2177-2250. [CrossRef] [PubMed]

4. De Vries, J.G. The Heck reaction in the production of fine chemicals. Can. J. Chem. 2001, 79, 1086-1092. [CrossRef]

5. Evangelisti, C.; Panziera, N.; Pertici, P.; Vitulli, G.; Salvadori, P.; Battocchio, C.; Polzonetti, G. Palladium nanoparticles supported on polyvinylpyridine: Catalytic activity in Heck-type reactions and XPS structural studies. J. Catal. 2009, 262, 287-293. [CrossRef]

6. Zhu, J.; Zhou, J.; Zhao, T.; Zhou, X.; Chen, D.; Yuan, W. Carbon nanofiber-supported palladium nanoparticles as potential recyclable catalysts for the Heck reaction. Appl. Catal. A-Gen. 2009, 352, 243-250. [CrossRef]

7. Firouzabadi, H.; Iranpoor, N.; Gholinejad, M.; Akbari, S.; Jeddi, N. Palladium nanoparticles supported on agarose-functionalized magnetic nanoparticles of $\mathrm{Fe}_{3} \mathrm{O}_{4}$ as a recyclable catalyst for $\mathrm{C}-\mathrm{C}$ bond formation via Suzuki-Miyaura, Heck-Mizoroki and Sonogashira-Hagihara coupling reactions. RSC Adv. 2014, 4, 17060-17070. [CrossRef]

8. Firouzabadi, H.; Iranpoor, N.; Ghaderi, A. Solvent-free Mizoroki-Heck reaction catalyzed by palladium nano-particles deposited on gelatin as the reductant, ligand and the non-toxic and degradable natural product support. J. Mol. Catal. A Chem. 2011, 347, 38-45. [CrossRef]

9. Lamblin, M.; Nassar-Hardy, L.; Hierso, J.C.; Fouquet, E.; Felpin, F.X. Recyclable heterogeneous palladium catalysts in pure water: Sustainable developments in Suzuki, Heck, Sonogashira and Tsuji-Trost reactions. Adv. Synth. Catal. 2010, 352, 33-79. [CrossRef] 
10. Khalafi-Nezhad, A.; Panahi, F. Immobilized palladium nanoparticles on a silica-starch substrate (PNP-SSS): As an efficient heterogeneous catalyst for Heck and copper-free Sonogashira reactions in water. Green Chem. 2011, 13, 2408. [CrossRef]

11. Palomo, J.M.; Filice, M. Biosynthesis of Metal Nanoparticles: Novel Efficient Heterogeneous Nanocatalysts. Nanomaterials 2016, 6, 84. [CrossRef] [PubMed]

12. Ghorbani-Choghamarani, A.; Taherinia, Z. Synthesis of peptide nanofibers decorated with palladium nanoparticles and its application as an efficient catalyst for the synthesis of sulfides via reaction of aryl halides with thiourea or 2-mercaptobenzothiazole. RSC Adv. 2016, 6, 59410-59421. [CrossRef]

13. Ghorbani-Choghamarani, A.; Taherinia, Z. Synthesis of biaryls using palladium nanoparticles immobilized on peptide nanofibers as catalyst and hydroxybenzotriazole as novel phenylating reagent. Chin. J. Catal. 2017, 38, 469-474. [CrossRef]

14. Jomma, E.Y.; Ding, S.N. One-Pot hydrothermal synthesis of magnetite prussian blue Nano-Composites and their application to fabricate glucose biosensor. Sensors 2016, 16, 243. [CrossRef] [PubMed]

15. Prastaro, A.; Ceci, P.; Chiancone, E.; Boffi, A.; Cirilli, R.; Colone, M.; Fabrizi, G.; Stringaro, A.; Cacchi, S. Suzuki-Miyaura cross-coupling catalyzed by protein-stabilized palladium nanoparticles under aerobic conditions in water: Application to a one-pot chemoenzymatic enantioselective synthesis of chiral biaryl alcohols. Green Chem. 2009, 11, 1929. [CrossRef]

16. Romero, O.; De las Rivas, B.; Lopez-Tejedor, D.; Palomo, J.M. Effect of Site-Specific Peptide-Tag Labeling on the Biocatalytic Properties of Thermoalkalophilic Lipase from Geobacillus thermocatenulatus. ChemBioChem 2018, 19, 369-378. [CrossRef] [PubMed]

17. Romero, O.; Filice, M.; De las Rivas, B.; Carrasco-Lopez, C.; Klett, J.; Morreale, A.; Hermoso, J.A.; Guisan, J.M.; Abian, O.; Palomo, J.M. Semisynthetic peptide-lipase conjugates for improved biotransformations. Chem. Commun. 2012, 48, 9053-9055. [CrossRef] [PubMed]

18. Filice, M.; Marciello, M.; del Puerto Morales, M.; Palomo, J.M. Synthesis of heterogeneous enzyme-metal nanoparticle biohybrids in aqueous media and their applications in $\mathrm{C}-\mathrm{C}$ bond formation and tandem catalysis. Chem. Commun. 2013, 49, 6876. [CrossRef] [PubMed]

19. Bradford, M.M. A rapid and sensitive method for the quantitation of microgram quantities of protein utilizing the principle of protein-dye binding. Anal. Biochem. 1976, 72, 248-254. [CrossRef]

20. Schmidt-Dannert, C.; Rúa, M.L.; Atomi, H.; Schmid, R.D. Thermoalkalophilic lipase of Bacillus thermocatenulatus. I. Molecular cloning, nucleotide sequence, purification and some properties. Biochim. Biophys. Acta Lipids Lipid Met. 1996, 1301, 105-114. [CrossRef]

Sample Availability: Samples of the compounds are not available from the authors.

(C) 2018 by the authors. Licensee MDPI, Basel, Switzerland. This article is an open access article distributed under the terms and conditions of the Creative Commons Attribution (CC BY) license (http:/ / creativecommons.org/licenses/by/4.0/). 